УДК 633.16«324»:632.111:631.559

(C) 2012

Ярчук І. І., доктор сільськогосподарських наук,

Божско В. Ю., аспірант*,

Войт В. А., студент

Дніпропетровський державний аграрний університет

\title{
ЗИМОСТІЙКІСТЬ ТА УРОЖАЙНІСТЬ СОРТІВ ЯЧМЕНЮ ОЗИМОГО
}

\section{Рецензент - доктор сільськогосподарських наук, професор О. П. Якунін}

Наведені результати досліджень сортової реакиії ячменю озимого на строки сівби та норми висіву насіння залежно від гідротермічних умов року.

Значна увага надається вивченню впливу строків сівби та норм висіву насіння на зимостійкість посівів ячменю озимого. Встановлено, щзо кращче від інших зимував сорт Сіндерела. Найвищою урожайністю виділявся вітчизняний сорт Основа за сівби в оптимальний для підзони строк-початок третьої декади вересня (22.09) із нормою висіву 3,5 млн схожого насіння на гектар.

Ключові слова: ячмінь озимий, строки сівби, норми висіву, зимостійкість, урожайність.

Постановка проблеми. Ячмінь був і залишається однією 3 провідних культур для України. Особливістю ячменю, що вирощується в умовах північного Степу України, є його висока поживна цінність, високий вміст білка. Сорти ячменю озимого до того ж вирізняються високою потенційною продуктивністю.

Ячмінь озимий має чимало переваг перед ярим. Головна перевага полягає в тому, що озимий має можливість уникнути дефіциту вологи наприкінці літа, що в нашій зоні спостерігається майже щорічно. Завдяки кращому розвитку рослин він легше переносить посуху. Поля 3-під ячменю озимого раніше вивільняються та можуть краще бути підготовлені під нову культуру. Відносно повільний розвиток рослин ячменю озимого на початку вегетації дає можливість більш ретельно проводити технологічні заходи. До того ж зерно ячменю озимого раніше потрапляє на ринок. Однак у той же час ячмінь озимий більш вибагливий до агротехніки, сильніше вражається хворобами [4].

У 1991 році в Дніпропетровській області ячмінь озимий займав 14 тис. га, у Запорізькій області - 35 тис. га, в Одеській - 100 тис. га. Останнім часом площі під ячменем озимим, на жаль, дещо скоротилися. Потенціал цієї культури досить високий. На сортовипробувальній ста- нції Прага-Рузине у 1971 році вже отримували урожай ячменю озимого 7,62 т/га [7]. Дещо пізніше, у 1982 році, на дослідних полях Ноттінгемського університету отримали 9,4 т/га зерна [5]. У 1984 році вже багатьма фермерами Великої Британії були отримані урожаї зерна ячменю озимого понад 10 тонн [8].

У той же час, незважаючи на всі переваги, ячмінь озимий має і значну ваду - досить низьку морозо- та зимостійкість. Саме через це площі посіву ячменю озимого залишаються вкрай незначними.

Аналіз основних досліджень і публікацій, у яких започатковано розв'язання проблеми. Вивченню зимостійкості ячменю озимого багато уваги приділялось як в Україні [2, 3], так і за кордоном [5, 6], але впровадження нових сортів, вирощування у нових умовах вимагає вивчення ïx реакції на основні технологічні заходи.

Мета і завдання досліджень. У зв'язку зі сказаним, ми в умовах північного Степу вивчали реакцію сортів ячменю озимого вітчизняної та закордонної селекції на строки сівби та норми висіву, особливості формування зимостійкості та продуктивності.

Матеріали i методи досліджень. Низку польових дослідів із вивчення зимостійкості сортів ячменю озимого було закладено восени 2009 року на дослідному полі Дніпропетровського державного аграрного університету на чорноземі звичайному малогумусному середньосуглинковому. Потужність гумусованого профілю 75 см. Вміст гумусу (за Тюріним) у верхній частині гумусо-акумулятивного горизонту становить 3,9-4,2 \%. Вміст у верхньому шарі грунту (0-20 см) азоту, що легко гідролізується (за Тюріним та Кононовою), становить 8,0-8,5 мг/100 г грунту, рухомого фосфору (за Чириковим) - 9,010,0 мг/100 г грунту і обмінного калію (за Масловою) - 14,0-15,0 мг/100 г грунту.

* Керівник-доктор сільськогосподарських наук I. I. Ярчук 
Погодні умови осені 2009 року відрізнялися сприятливими умовами для росту й розвитку рослин як ранніх, так i пізніх строків сівби. Постійні та рясні опади восени й на початку зими, а також підвищені температури (плюсові температури утримувалися включно до другої декади грудня) 3 частими і глибокими відлигами сприяли тому, що рослини дещо переросли. Восени 2010 року умови для рослин склалися значно гірше: надзвичайно посушливі умови влітку і недостатня кількість опадів в осінній період призвели до недостатнього розвитку рослин у кінці осінньої вегетації, недостатнього загартування.

У ході проведення польових досліджень було використано загальноприйняту методику [1]. Облікова площа ділянок становила $30 \mathrm{~m}^{2}$, із триразовим повторенням.

Результати досліджень. На час припинення осінньої вегетації за оптимального строку сівби кращим габітусом (висотою й масою) відрізнявся сорт вітчизняної селекції Основа. Проте найбільшого ступеня розвитку (за кількістю стебел і вузлових коренів) у всі строки сівби досяг сорт Сіндерела; дещо нижчі показники мав і сорт Луран.

В осінній період норми висіву насіння на висоту рослин досліджуваних сортів не вплинули. Розвиток рослин усіх сортів зі збільшенням норми висіву насіння помітно пригнічувався, - вони менше утворювали стебел і вузлових коренів. На глибину залягання вузла кущіння норми висіву насіння у 2009 році суттєвого впливу не мали.

Ступінь розвитку ячменю в осінній період безпосередньо вплинув на виживаність рослин. Найбільш стійкими до несприятливих умов зимівлі були молоді рослини пізнього строку сівби. 3-поміж сортів краще інших перезимував сорт Сіндерела, а найменшу стійкість виявив Луран (табл. 1).

Суттєва різниця в умовах осінньої вегетації призвела до того, що сорти по-різному загартовувалися й мали різну по роках витривалість до несприятливих умов зимівлі. За сприятливих умов осіннього розвитку рослин при достатній вологозабезпеченості та підвищених температуpax (2009 р.) максимальну стійкість формував сорт Сіндерела. Резистентність сортів Основа та Луран за таких умов суттєво знизилася.

В умовах осені 2010 року (що більше відповідають кліматичним умовам зони) кращу виживаність показав сорт Основа.

Залежно від норм висіву найбільшу стійкість до несприятливих умов зимівлі серед сортів, як i в попередньому досліді, також мав сорт Сіндерела (табл. 2). Що стосується сортів Основи та Лурану, то вони значно поступалися за резистентністю Сіндереллі. Слід зазначити, що сорт Основа відносно Лурану виявив більшу стійкість за підвищеної норми висіву - 5,5 млн шт. схожого насіння на гектар, а Луран - меншій нормі висіву (3,5 млн шт. схожого насіння на гектар).

1. Перезимівля сортів ячменю озимого залежно від строків сівби, \% рослин, щңо збереглися

\begin{tabular}{|c|c|c|c|c|c|c|c|c|}
\hline \multicolumn{9}{|c|}{ Copт } \\
\hline \multicolumn{3}{|c|}{ Основа } & \multicolumn{3}{|c|}{ Луран } & \multicolumn{3}{|c|}{ Сіндерела } \\
\hline \multicolumn{9}{|c|}{ Строк сівби } \\
\hline 15.09 & 22.09 & 29.09 & 15.09 & 22.09 & 29.09 & 15.09 & 22.09 & 29.09 \\
\hline \multicolumn{9}{|c|}{2010 рік } \\
\hline 39,8 & 55,9 & 69,1 & 26,5 & 51,9 & 63,6 & 80,7 & 90,0 & 90,0 \\
\hline \multicolumn{9}{|c|}{2011 рік } \\
\hline 99,3 & 93,4 & 98,7 & 99,3 & 91,8 & 97,7 & 98,8 & 91,5 & 93,8 \\
\hline \multicolumn{9}{|c|}{ Середнє } \\
\hline 69,6 & 74,7 & 83,9 & 62,9 & 71,9 & 80,7 & 89,8 & 90,8 & 91,9 \\
\hline
\end{tabular}

2. Перезимівля сортів ячмено озимого залежно від норм висіву насіння у 2010-2011 роках, \% рослин, що збереглися

\begin{tabular}{|c|c|c|c|c|c|c|c|c|c|}
\hline \multirow{4}{*}{ Рік } & \multicolumn{9}{|c|}{ Сорт } \\
\hline & \multicolumn{3}{|c|}{ Основа } & \multicolumn{3}{|c|}{ Луран } & \multicolumn{3}{|c|}{ Сіндерела } \\
\hline & \multicolumn{9}{|c|}{ Норма висіву, млн шт. схожого насіння } \\
\hline & 3,5 & 4,5 & 5,5 & 3,5 & 4,5 & 5,5 & 3,5 & 4,5 & 5,5 \\
\hline 2010 & 72,2 & 66,8 & 77,6 & 82,1 & 66,5 & 70,8 & 100 & 100 & 100 \\
\hline 2011 & 93,1 & 100 & 98,8 & 87,8 & 95,5 & 98,4 & 87,4 & 94,7 & 85,1 \\
\hline Середнє & 82,7 & 83,4 & 88,2 & 85,0 & 81,0 & 84,6 & 93,7 & 97,4 & 92,6 \\
\hline \multicolumn{10}{|c|}{$\mathrm{HIP}_{05}$ y 2010 p. $-5,7 ;$ y 2011 p. $-7,5$} \\
\hline
\end{tabular}




\section{СІЛЬСЬКЕ ГОСПОДАРСТВО. РОСЛИННИЦТВО}

Розвиток рослин ячменю озимого восени (незважаючи на часткову загибель їх узимку) багато в чому обумовлює стан рослин навесні. Найбільш розвинутими після зимівлі залишаються рослини раннього строку сівби. Проте слід зауважити, що відмінності, зокрема по масі та висоті, дещо скоротилися. Це відбулося через більшу втрату листостеблової маси менш стійких рослин раннього строку сівби.

Умови весняного розвитку рослин були відносно сприятливі: достатня кількість вологи в грунті, часті опади, помірна температура. Все це сприяло добрій регенерації рослин і накопиченню листостеблової маси. Проте в 2010 році, коли розпочався процес наливу зерна, погодні умови стали через сильну спеку та посуху вкрай несприятливі. Наслідком цього було значне зниження урожаю, передусім рослин із добре розвинутим листостебловим апаратом. Це призвело до ще більшого зміщення оптимальних строків сівби в 2010 році у бік пізніх (табл. 3). У зв'язку зі зміщенням оптимального строку сівби на кінець третьої декади вересня, восени 2010 року ячмінь висіяли ще в один строк -6 жовтня.
У середньому за роки досліджень оптимальним строком сівби був початок третьої декади вересня (22.09). Дослідження виявили також і сортову реакцію на строки сівби. Так, сорт Луран краще себе виявляв за сівби в оптимальні (22.09) та пізні строки (29.09), а сорт Сіндерела менше знижував урожайність при відхиленні строків сівби в бік ранніх. Сорт Основа майже однаково сильно знижував урожайність при відхиленні від оптимального строку сівби.

Найвищу урожайність серед сортів за роки досліджень формував сорт Основа (в середньому 4,09 т/га).

Не однаковою була реакція сортів і на норми висіву насіння (табл. 4). Високопродуктивний сорт Основа формував найвищу урожайність за найменшої (відносно інших сортів) норми висіву $-3,5$ млн штук схожого насіння на гектар.

Сорт чеської селекції Сіндерела в середньому за роки досліджень також виявив більшу урожайність за найменшої норми висіву (3,5 млн/га), а сорт Луран максимальну продуктивність сформував за норми висіву 4,5 млн схожого насіння на гектар.

3. Урожайність сортів ячменю озимого залежно від строків сівби у 2010-2011 pp., m/2a

\begin{tabular}{|c|c|c|c|c|c|}
\hline \multicolumn{2}{|c|}{ Варіант } & \multicolumn{4}{c|}{ Строк сівби } \\
\hline Рік & сорт & 15.09 & 22.09 & 29.09 & 6.10 \\
\hline \multirow{3}{*}{2010} & Основа & 1,57 & 3,06 & 3,22 & - \\
\cline { 2 - 6 } & Луран & 1,46 & 2,56 & 3,00 & - \\
\cline { 2 - 6 } & Сіндерела & 2,76 & 3,00 & 2,75 & - \\
\hline \multirow{3}{*}{ Середнє } & Основа & 4,77 & 5,11 & 4,31 & 4,00 \\
\cline { 2 - 6 } & Луран & 3,59 & 3,67 & 3,29 & 3,11 \\
\cline { 2 - 6 } & Сіндерела & 4,01 & 4,19 & 2,78 & 2,32 \\
\cline { 2 - 6 } & Основа & 3,17 & 4,09 & 3,77 & - \\
\cline { 2 - 6 } & Луран & 2,52 & 3,11 & 3,15 & - \\
\hline \multicolumn{2}{|c|}{ Сіндерела } & 3,39 & 3,59 & 2,77 & \\
\hline
\end{tabular}

4. Урожайність сортів ячменю озимого залежно від норми висіву у 2010-2011 pp., m/2а

\begin{tabular}{|c|c|c|c|c|c|}
\hline \multicolumn{2}{|c|}{ Варіант } & \multicolumn{4}{|c|}{ Норма висіву, млн шт. схожого насіння } \\
\hline Рік & сорт & 2,5 & 3,5 & 4,5 & 5,5 \\
\hline \multirow{3}{*}{2010} & Основа & - & 3,14 & 2,97 & 2,94 \\
\hline & Луран & - & 3,02 & 3,13 & 2,85 \\
\hline & Сіндерела & - & 3,40 & 2,94 & 3,12 \\
\hline \multirow{3}{*}{2011} & Основа & 3,96 & 4,54 & 4,49 & 4,69 \\
\hline & Луран & 3,51 & 3,66 & 4,03 & 3,99 \\
\hline & Сіндерела & 2,76 & 2,80 & 3,02 & 3,02 \\
\hline \multirow{3}{*}{ Середнє } & Основа & - & 3,84 & 3,73 & 3,82 \\
\hline & Луран & - & 3,34 & 3,58 & 3,42 \\
\hline & Сіндерела & - & 3,10 & 2,98 & 3,07 \\
\hline \multicolumn{6}{|c|}{ HIP $_{0,5}$ y 2010 p. $-0,32 ;$ y 2011 p. $-0,16$} \\
\hline
\end{tabular}


Слід зазначити, що в посушливому 2010 році сорти формували набільшу продуктивність при найменшій нормі висіву, а у відносно вологому 2011 році кращою нормою висіву виявилася більш висока норма висіву (4,5 та 5,5 млн/га). Ця тенденція притаманна всім сортам, але у сортів чеської селекції - як більш вибагливих до зволоження грунту - вона була більше виражена.

Через значну контрастність в умовах вирощування по роках усереднені дані за роки досліджень показують, що лише сорт Луран потребує сівби більш високою нормою висіву (4,5 млн/га), ніж сорти Основа та Сіндерела (3,5 млн/га).

\section{Висновки:}

1. Найбільшу стійкість до несприятливих умов

\section{БІБЛІОГРАФІЯ}

1. Доспехов Б. А. Методика полевого опыта. - М. : Колос. 1979. $-416 \mathrm{c}$.

2. Черенков А. В., Бондаренко А. С., Бенда Р. В. Зимостійкість рослин озимого ячменю залежно від строків сівби в умовах північної частини Степу // Агроном. - 2011. - № 3. - С. 82-84.

3. Ярчук I. I., Божко В. Ю., Невтриніс А. В. Визначення критеріїв пересіву ушкоджених взимку посівів ячменю озимого // Агроном. - 2012. № 1 (35). - C. 86-87.

4. Coles G. D. Winter barley - yes or no // DSIR Cereal News. - 1984. - № 10. - P. 17-19. зимівлі мали молоді рослини пізніх строків сівби. Найбільш резистентним виявився сорт Сіндерела, гірше за всіх перезимовував сорт Луран.

2. Найвищу урожайність серед сортів формував сорт Основа за сівби в оптимальний для зони строк - початок третьої декади вересня (22.09). Він негативно реагував на зміщення строків сівби як у бік ранніх, так і в бік пізніх. Сорт Луран менше знижував урожайність при відхиленні від оптимального строку в бік пізніх, а сорт Сіндерела - в бік ранніх.

3. Оптимальною нормою висіву для сортів Основа та Сіндерела є 3,5 млн схожого насіння на гектар, а сорт Луран краще висівати при більш високій нормі (4,5 млн шт./га).

5. Green C., Furston D., Ivins J. Time of sowing the yield of winter barley // J. agr. Sc. - 1985. - № 104. - P. 405-411.

6. Kasper $W$. Zur Reaktion der Sortenwertprufungen // Tag.-Ber. / Akad. Landwirtsch. - Wiss. DDR. Berlin. - 1984. - № 219. - P. 199-209.

7. Vlasak M., Bares I., Apltauerova M. Srovnani prodaktivity ozimeho jecmene a ozime psenice // Sb. UVTIZ. Genet. a slecht. - 1983. - V. 19. - № 4. - P. 259-267.

8. Winters barley of northern promise. Farmers Weekly. - 1984. - V. 100. - № 6. - P. 5-6. 